\title{
Genderově citlivé vzdělávání jako prostředek k vytváření inkluzivního školního prostředí: Porovnání situace v České republice, Rakousku a Mad'arsku
}

\author{
Dagmar Krišová
}

\section{Kontakt \\ Masarykova univerzita Pedagogická fakulta \\ Porričí 31a 60300 Brno \\ krisova@mail.muni.cz}

$\triangle$ Korespondence: krisova@mail.muni.cz

Copyright (C) 2019 by the author and publisher, TBU in Zlín. This work is licensed under the Creative Commons Attribution International License (CC BY).

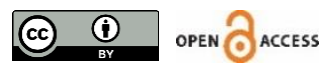

\begin{abstract}
Abstrakt: Článek představuje inkluzivní vzdělávání jako vzdělávání genderově citlivé. Genderově citlivé vzdělávání a inkluzi spojuje společný cíl spravedlivého vzdělávání pro všechny bez ohledu na jejich genderovou identitu, sexuální orientaci, rasu, etnicitu, třídní příslušnost, náboženství či zdravotní „postižení". Výzkumy ukazují, že vyučující mají tendenci kžákům a žákyním pristupovat na základě stereotypních představ o schopnostech a dovednostech chlapců/mužů a dívek/žen. Tyto představy pak mají vliv na aspirace studujících a jejich budoucí uplatnění. Studie prezentuje dílčí výsledky mezinárodního projektu Towards Gender Sensitive Education, který pomocí obsahové kvalitativní analýzy zkoumal zakotvení genderové rovnosti a konceptualizaci genderu v oficiálních dokumentech školské politiky v České republice, Rakousku a Mad'arsku. Analýza legislativních, strategických a kurikulárních dokumentů a relevantních příruček ukázala tři odlišné př́stupy $\mathrm{k}$ tematizaci genderové rovnosti, a tedy $\mathrm{i}$ tři odlišné př́stupy $\mathrm{k}$ pojetí spravedlivého, inkluzivního - genderově citlivého školství.
\end{abstract}

Klíčová slova: gender, genderově citlivé vzdělávání, genderová rovnost, inkluzivní prostředí, obsahová analýza

\section{Gender-sensitive education as a tool for building an inclusive school environment: Comparison of the situation in the Czech Republic, Austria, and Hungary} Abstract: The article introduces inclusive education as gender-
sensitive education. Gender-sensitive education and inclusion
are joined by a common goal of fair education for all regardless
of gender identity, sexual orientation, race, ethnicity, religion or
disability. Research shows teachers tend to approach female and
male pupils differently on the basis of stereotypical ideas about
the abilities and skills of boys/men and girls/women. These ideas
influence pupils' aspirations and future occupations. The study
presents partial results of the Towards Gender-Sensitive
Education project, which used qualitative content analysis to
examine the conceptualization of gender and gender equality in
official documents of educational policies in the Czech Republic,
Austria, and Hungary. The analysis of legislative, strategic and 
curricular documents and relevant handbooks showed three different approaches to gender equality and therefore three different approaches to fair, inclusive and gender-sensitive education.

Keywords: gender, gender-sensitive education, gender equality, inclusive environment, content analysis

\section{1 Úvod}

O tom, že český vzdělávací systém není spravedlivý a neumožňuje všem dětem rozvinout naplno jejich potenciál, není sporu. Nerovnost v českém vzdělávacím systému dokládají výzkumné studie, mezinárodní srovnávací testy, zmiňují ji národní strategické dokumenty a je dlouhodobě kritizována mezinárodními institucemi. Při diskuzích o inkluzivním vzdělávání, tedy takovém, které zajišt́uje všem dětem rovné podmínky a přiležitosti v přístupu ke vzdělávání i jeho dalším průběhu, jsou zpravidla akcentována témata, jako je nedostupnost hlavního vzdělávacího proudu pro děti se zdravotním „postižením“" ${ }^{\prime \prime}$ nedostatečná podpora pro děti ze sociálně znevýhodněného prostředí nebo děti s odlišným mateřským jazykem, př́ípadně stále př́tomná segregace romských žáků a žákyň. Všechny zmíněné projevy nerovnosti jsou vážné a jejich přetrvávání nepřijatelné, rádi bychom však poukázali na fakt, že v debatách o inkluzi a inkluzivním vzdělávání často chybí optika genderové nerovnosti. Gender představuje jeden ze základních aspektů mocenského uspořádání naší společnosti a nutně se prolíná i s dalšími osami nerovnosti, jako je třída, rasa a etnicita, zdravotní „postižení“, sexuální orientace, věk či náboženství. Jsme proto přesvědčeni, že pro dosažení spravedlivého a inkluzivního vzdělávacího systému je nutné gender zohledňovat a prosazovat genderově citlivý přístup k výuce.

Kritickou reflexi genderových stereotypů a jejich dopadů na život dětí ve škole považujeme za nezbytný aspekt inkluzivní školy, jež chce zajistit rovné šance na vzdělání všem dětem a jež na jednotlivé žáky a žákyně nahliží jako na nositele jedinečných životních zkušeností. Školy, které se podílí na udržování a posilování genderových stereotypů stavějících na představě o zásadních odlišnostech mužského a ženského světa, omezují žáky a žákyně v plném využití jejich potenciálu. Řada dětí je podporována $v$ rozvoji jen části svých schopností a kompetencí - těch, které jsou přisuzovány príslušníkům a př́slušnicím jejich pohlaví. Nereflektované stereotypy také exkludují děti a studující, kteří se stereotypním genderovým představám vymykají.

Předkládaná studie porovnává, jak je gender a genderově citlivé vzdělávání zakotveno v dokumentech školských politik v České republice, Mad’arsku a Rakousku. Jinými slovy porovnává, jaké, pokud vůbec nějaké, se dostává školám a vyučujícím v daných zemích podpory $\mathrm{k}$ uplatňování genderově citlivého vzdělávání, a tedy k vytváření inkluzivního školního prostředí. Všechny tři země se $z$ hlediska genderu potýkají v oblasti vzdělávání s podobnými problémy, k prosazování genderové rovnosti však přistupují odlišně. Rakouské institucionální zakotvení genderové perspektivy do vzdělávacího systému může být pro českou praxi inspirací. Naopak situace v Mad'arsku představuje spíše varování a směr, jímž by se Česká republika při snaze zajistit spravedlivé vzdělání pro všechny děti ubírat neměla. Dřive než představíme výsledky analýzy, zastavíme se blíže u problematiky genderové nerovnosti a genderových stereotypů ve vzdělávání a u konceptu genderově citlivého vzdělávání.

1 Pojem „postižení uvádíme záměrně v uvozovkách a přebíráme vysvětlení tohoto užití od Kolářové, která uvadí, že pojem „neodkazuje, jak je obvyklé, kjinakosti těla či mysli, nýbrž ke společenským mechanismům vylučování a stigmatizace, „postihujícím“ osoby, jejichž tělesnost a intelekt neodpovídají domněle univerzálně platným a zdánlivě přirozeným parametrům normality“ (2012, s. 11). 


\section{Genderová nerovnost a genderová citlivost ve vzdělávání}

Žijeme v době a zemi, kde přístup k základnímu vzdělávání není ovlivněn genderem, jeho průběh však již genderovou nerovností zatížen je. Vyučující často $k$ dětem a studujícím přistupují s genderově stereotypními představami a očekáváními (Mizala, Martínez, \& Martínez, 2015), které ovlivňuji jejich komunikaci s nimi (Jarkovská, 2013; Vad'urová, 2011), jejich hodnocení (Drexlerová, 2018) i samotné výkony studujících (Batalha \& Reynolds, 2013). Genderové stereotypy nalezneme v učebních materiálech i v uspořádání a výzdobě školního prostoru, jsou součástí oficiálního i skrytého kurikula (Kollmayer, Schober, \& Spiel, 2018; Slavík, 2019).

Jedním ze snadno pozorovatelných důsledků genderovanosti školního prostředí je fakt, že dívky a chlapci volí po základní škole odlišné studijní cesty a ve velké míře směřují do genderově segregovaných oborů („Český statistický úřad“, 2019; Jarkovská, Lišková, \& Šmídová a kol., 2010), což se následně odráží v jejich budoucím uplatnění a finančním zajištění. Volbu odlišných studijních drah, jež významně determinuje budoucí pracovní i rodinný život žáků a žákyň, nelze vysvětlovat přirozenými/biologickými odlišnostmi mezi muži a ženami nebo svobodnou volbou dětí. Ačkoliv neexistuje jedna univerzálně přijímaná teorie genderové socializace a genderového vývoje, je při výkladu genderových odlišností nutné zohlednit působení genderových stereotypů a historický a společenský kontext (Batalha \& Reynolds, 2013). Za svobodnou pak nelze označit takovou volbu, která není o existenci a vlivu genderových stereotypů informovaná.

Dalším problémem vzdělávání a školních kolektivů, jenž má původ v genderovém uspořádání společnosti, je př́tomnost sexuálního a genderově podmíněného násilí, s nímž se studující setkávají i ze strany vyučujících (Smetáčková \& Pavlík, 2011, 2012; Vohlídalová, 2009)², a homofobní šikany³. Genderové stereotypy ovlivňují všechny děti a studující, zvláště nepřiznivě ale dopadají na ty, kteří se vymykají stereotypním představám o ženách/dívkách a mužích/chlapcích - tedy binárnímu rozdělení světa na mužský a ženský. Děti a studující, kteří jsou intersexuální, trans*, homosexuální, bisexuální nebo jinak genderově nekonformní si mohou připadat (a často reálně jsou) vyloučení - at' už z důvodu výše zmíněné homofobní šikany a obtěžování, nebo protože jsou v kurikulu neviditelní a jejich identita není běžně ze strany vyučujících a výukových materiálů legitimizována. Výzkumné studie ukazují, že LGBTI+ osoby jsou více než heterosexuální a genderově konformní osoby ohroženy duševními onemocněními, jako jsou deprese, úzkostné stavy, závislost na omamných látkách nebo sebevražedné sklony. LGBTI+ lidé čelí velkému stresu spojenému se skrýváním jejich identity nebo sexuální orientace, coming-outem a následnou homofobií (Charbonnier, Hatteschweiler, \& Graziani, 2015; Johns, Poteat, Horn, \& Kosciw, 2019; King et al., 2008).

Prostředí školy hraje v životě LGBTI+ dětí a studujících významnou roli, vytvoření inkluzivního klimatu je klíčové pro zajištění jejich zdravého duševního a emočního rozvoje. Výzkum veřejné ochránkyně práv (2019) ukazuje, že v tom řada současných škol selhává. Škola je místem, kde se LGBTI+ osoby setkávají s negativními komentári, prípadně místem, kde svou genderovou identitu nebo sexuální orientaci z obav skrývají nebo zatajují. Inkluzivní škola by měla být bezpečným místem, kde sexuální násilí

2 Výzkumy věnující se sexuálnímu obtěžování studujících ze strany vyučujících byly realizovány na středních a vysokých školách. Situace na základních školách dosud nebyla výzkumně zmapována. Není však důvod se domnívat, že by k sexuálnímu a genderově podmíněnému obtěžování na základních školách nedocházelo.

3 „Homofobní šikana představuje dlouhodobé a opakované verbální či fyzické ubližování člověku z důvodu, že není heterosexuální, nebo z důvodu, že se chová či vypadá odlišně, a je proto za gaye či lesbu označován. Homofobní obtěžování a šikana mají původ v heteronormativitě genderového raádu, který staví homosexuální, bisexuální a transsexuální lidi do asymetrického postavení vưči heterosexuálním lidem“ (Smetáčková \& Braun, 2009, s. 17).

4 Intersexuální jsou osoby, jež se narodily s kombinací ženských a mužských pohlavních znaků. Trans* osoby jsou lidé, jejichž genderová identita neodpovídá genderu, jenž jim byl přiřčen na základě biologického pohlaví. Homosexuální osoby jsou emočně i sexuálně přitahovány k osobám stejného biologického pohlaví. Bisexuální osoby jsou emočně a sexuálně přitahovány $\mathrm{k}$ mužům i ženám. 
a homofobní šikana nemají místo a kde žádné dítě nemusí z obav z reakcí spolužáků a spolužaček skrývat svou identitu. $\mathrm{K}$ tomu je však zapotřebí, aby byli vyučující genderově citliví a aktivně podobným projevům předcházeli, př́padně je uměli včas zachytit a efektivně řešit.

Genderově citlivým vzděláváním rozumíme přistup, jenž umožňuje rozvíjet potenciál všech dětí a studujících bez ohledu na jejich gender a který je současně kritický ke stávajícímu genderovému a nerovnému uspořádání společnosti. $V$ zahraniční literatuře se můžeme setkat s rozlišením genderově citlivého (gender-sensitive), genderově uvědomělého (gender aware) a na gender reagujícího (genderresponsive) vzdělávání. Přičemž někteří autoři a autorky považují výše zmíněné za jednotlivé na sebe navazující kroky, kdy genderová citlivost (sensitivity) je prvním stupněm spočívajícím ve schopnosti rozpoznat genderové jevy. Genderové povědomí (gender awareness) navazuje schopností rozpoznat problémy vyvěrající z genderové nerovnosti, a to i takové, které nejsou zřetelné na první pohled. Gender "responsiveness", již Ize rovněž přeložit jako citlivost, ovšem takovou, která spočívá v rychlé a pozitivní reakci, pak odkazuje ke schopnosti aktivně zasahovat proti genderovým předsudkům a diskriminaci a schopnosti zajistit genderovou rovnost („FAWE“, 2019). V české literatuře se používá termín genderově citlivé vzdělávání ve smyslu zahrnujícím všechny výše zmíněné kroky.

Souhlasíme s Jarkovskou (2007), jež uvádí, že základem genderově citlivého vzdělávání je uznání relevance genderu a zvědomění faktu, že žijeme v genderované ${ }^{5}$ společnosti, $v$ níž se gender dynamicky promítá do školní třídy a fungování celé školy. Bez připuštění existence genderových stereotypů a faktu, že řada genderových odlišností je důsledkem působení společnosti, nikoliv biologických rozdílů mezi muži a ženami, nelze genderově citlivý přístup aplikovat. Dalším důležitým aspektem je ochota proti genderovým nerovnostem vystoupit a reflektovat vlastní stereotypní jednání. Haring a Mörth (2009) za klíčový aspekt genderově citlivého vzdělávání považují sebereflexi vyučujících ve smyslu schopnosti nahlédnout na vlastní předpoklady a předsudky týkající se genderu a genderových identit studujících. Základem genderově citlivého vzdělávání je podle nich snaha vyučujících zbavovat se svých genderových stereotypů.

Doplňujeme, že ne pouze genderových stereotypů. Jak uvádí Lahelma (2014), gender je vždy nutné vnímat v souvislostmi s dalšími kategoriemi, jako je věk, etnicita, sexualita, zdraví apod. Právě zvědomění i dalších kategorií ukazuje, že neexistuje univerzální kategorie ženy/dívky nebo muži/chlapci, nebot naše životy jsou nutně ovlivněny i dalšími faktory. Je proto třeba klást si otázky, nejen čím jsou utvářeny naše předpoklady a očekávání o dívkách a chlapcích, ale též čím jsou utvářeny naše předpoklady a očekávání o dívkách a chlapcích jiného etnika či národnosti, jiného vyznání apod.

Gullberg, Andersson, Danielsson, Scantlebury a Hussénius (2018) navrhli model procesu genderově uvědomělého učení, jenž je založen na třech klíčových aktivitách - rozpoznání, sebereflexi a protiakci/zpochybnění. $V$ první ŕadě je podle nich nutné rozpoznat, $v$ jakých situacích hraje gender roli, rozpoznání vede k sebereflexi a následné protiakci vǔči genderově stereotypnímu jednání (žáků a žákyň, vyučujících, rodičů a dalších aktérů a aktérek). Všechny tři složky jsou však vzájemně provázané. Ve chvíli, kdy člověk rozezná genderovanou situaci, může zpochybnit její stereotypní schéma a vymezit se proti němu. Současně ve chvíli, kdy vidí někoho vymezovat se proti stereotypním schématům, může dospět $k$ sebereflexi vlastních předsudků a současně ke schopnosti rozpoznat podobnou situaci v budoucnu.

Vyučující, kteří se rozhodnou aplikovat genderově citlivé vzdělávání se vydávají na nelehkou cestu, která nemá dohledný cíl. Při nabourání genderových stereotypů

\section{Směřování k genderové}

cilitvosti je nikdy nekončící

proces posouvání vlastních

hranic i hranic ostatních

a zvědomování našich

předsudků

a předporozumění.

5 Pojem „genderovaný“ uživáme ve smyslu genderem a genderovým uspořádáním společnosti ovlivněný, respektive ve smyslu uvažující $v$ intencích mužských a ženských sfér a považující mužskou sféru za nadřazenou. 
se mohou setkat s nepochopením kolegů a kolegyň, rodičů i samotných dětí, které, jak ukazuje Smetáčková (2016) a zmiňuje Bussey (2013), jsou významnými strážci genderového raádu. Směřování k genderové citlivosti je nikdy nekončící proces posouvání vlastních hranic i hranic ostatních a zvědomování našich předsudků a předporozumění. V České republice existuje několik príruček ${ }^{6}$ pro pedagogické pracovníky a pracovnice, které nabízejí bližší vhled do genderové problematiky ve vzdělávání, podněcují sebereflexi a nabízejí konkrétní aktivity, jež je možné k otevírání genderových témat použít ve vyučování. Příručky představují důležitou metodickou podporu těm vyučujícím, kterým záleží na vytváření spravedlivějšího a inkluzivního školního prostředí. Podpora je však nutná i z institucionální úrovně, ze strany MŠMT a vzdělávací politiky. Jak je genderově citlivé vzdělávání v České republice prosazováno, představíme vporovnání se situací v Mad'arsku a Rakousku v následujících částech našeho článku.

\section{Genderová nerovnost ve vzdělávacích dokumentech - porovnání situace v České republice, Mad'arsku a Rakousku}

Předkládaná studie vychází z tř́letého mezinárodního projektu Towards Gender Sensitive Education (TGSE), jehož cílem je posílit genderové povědomí a genderovou citlivost stávajících a budoucích vyučujících prostřednictvím kurzů genderově citlivého vzdělávání. Projekt je realizován pěti partnerskými organizacemi z České republiky, Mad’arska a Rakouska v letech 2017-2020. V první fázi projektu byla vypracována studie (Rédai \& Sáfrány, 2019) scílem porovnat situaci v partnerských zemích. Výzkumná studie obsahovala tři části - analýzu vzdělávacích dokumentů mapující konceptualizaci genderu a genderové rovnosti, pozorování na základních školách a fokusní skupiny s vyučujícími na základních školách, studujícími pedagogických oborů a vzdělavateli a vzdělavatelkami v oblasti genderově citlivého vzdělávání. V článku se budeme věnovat pouze první ze zmíněných částí , tedy výsledkům analýzy vzdělávacích dokumentů.

Analyzovali jsme legislativní dokumenty upravující školní vzdělávání a vzdělávání vyučujících včetně antidiskriminačních zákonů, strategické dokumenty pro prosazování genderové rovnosti, kurikulární dokumenty se zaměěením na dokumenty upravující výuku žáků a žákyň na druhém stupni ${ }^{8}$ základních škol a př́ručky vztahující se k genderově citlivému vzdělávání vydané příslušnými ministerstvy školství nebo s jejich spoluprací. Analýza byla realizována partnerskými organizacemi ${ }^{9}$ v jednotlivých zemích na jaře 2018, její součástí jsou proto dokumenty platné v tomto období. Seznam analyzovaných dokumentů uvádíme v príloze.

Základní výzkumná otázka rámující analýzu zněla: Jak je koncept genderu a genderové rovnosti/spravedlnosti zahrnut v národních vzdělávacích dokumentech, kurikulárních dokumentech

6 Například: Gender ve škole (Smetáčková, 2019), Genderově citlivá výchova: Kde začít? (Babanová \& Miškolci, 2007), Homofobie v žákovských kolektivech (Smetáčková \& Braun, 2009), Volba povolání bez předsudků (Kolářová a kol, 2014), Dvanáct ověřených metod pro rozvoj kolegiální spolupráce (Babanová, 2019).

7 Fokusní skupiny a pozorování na školách nebyly na rozdíl od analýzy dokumentů prováděny podle jednotné metodologie, každá z partnerských organizací zvolila vlastní otázky, cílové skupiny a způsob zpracování získaných dat. Výsledky sloužily především pro další fázi projektu - tvorbu kurzu genderově citlivého vzdělávání.

8 Na tuto cílovou skupinu byl zaměřen projekt TGSE, proto se $v$ analýze věnovali pouze kurikulárním dokumentům věnujícím se vzdělávání žáků a žákyň v tomto stupni. V Mad’arsku a Rakousku na rozdíl od České republiky začíná (u nás tzv.) druhý stupeň již v páté tř́dě a stejně jako v České republice trvá čtyři roky. Ve všech třech zemích je přechod na druhý stupeň spojen s možností volby pokračování ve studiu na různých typech škol.

9 Analýzu rakouských dokumentů realizovaly Claudia Schneider a Renate Tanzberger z organizace Verein EfEU (Asociace pro rozvoj feministického vzdělávání a výukových modelů). Mad’arské dokumenty analyzovaly Dorottya Rédai (Univerzita Eötvös Loránd) a Réka Sáfrány (Mad’arská ženská lobby). Analýzu českých dokumentů zpracovala autorka tohoto textu. 
a oficiálních prríručkách? Při samotné analýze jsme postupovali pomocí návodných otázek inspirovaných přistupem Dombos, Krizsan, Verloo a Zentai (2012). Ptali jsme se na následující - Je v daném dokumentu gender explicitně nebo implicitně zmíněn? Pokud ne, jaký by mohl být důvod? Pokud ano, v jaké časti dokumentu je zmíněn a jak je rámován (rovné príležitosti, lidská práva, diskriminace, ekonomická seberealizace apod.)? Jakými referencemi je rámování genderu podpořeno? Je $v$ dokumentu genderová nerovnost považována za problematickou? Navrhuje dokument opatření/změny pro dosažení genderové rovnosti? Jaké? Obsahuje dokument nějaká slepá místa? Jaká?

Dokumenty, které se specificky věnovaly genderu a genderové rovnosti, byly dále podrobeny otázkám - Jak je gender a genderová rovnost konceptualizována? Pohledem rozdílnosti mužů a žen, pohledem rovnosti, prostřednictvím dekonstruktivistické teorie genderu, queer perspektivy, heteronormativního pohledu? Jaká slova a terminologie jsou používány v souvislosti s genderem? Jak (pokud vůbec) je gender vztahován $\mathrm{k}$ dalším důvodům/typům nerovnosti?

Předkládané výsledky vycházejí z analýzy 14 legislativních dokumentů (4 českých, 4 mad’arských a 6 rakouských), 10 strategických dokumentů (2 evropských, 4 českých, 1 mad’arského, 3 rakouských), 7 kurikulárních dokumentů (1 českého, 2 mad'arských, 4 rakouských) a 11 príruček a doporučení (7 rakouských a 4 českých) $)^{10}$.

\subsection{Legislativní dokumenty}

V této části představíme výsledky analýzy legislativních dokumentů upravujících vzdělávání $v$ jednotlivých zemích. Jedná se o antidiskriminační, školské a vysokoškolské zákony doplněné o české nařizení vlády o oblastech vzdělávání ve vysokém školství, rakouskou novelu zákona o službách upravující práva a povinnosti vyučujících na veřejných školách, rakouský vzdělávací princip k rovnosti žen a mužů a mad'arskou ministerskou vyhlášku upravující některé jiné vyhlášky veřejného vzdělávání.

Všechny tři země $v$ minulosti přijaly zákony o rovném zacházení / antidiskriminační zákony. Ve všech zemích je zakázána diskriminace z důvodu pohlaví i sexuální orientace a za diskriminaci se považuje i sexuální obtěžování. Rakouská legislativa používá slovo "Geschlecht", jež odkazuje jak k biologickému pohlaví, tak genderu a vztahuje se k mužům, ženám a transsexuálním osobám. Mad'arská legislativa používá pojem "nem“, který rovněž odkazuje k biologickému pohlaví i genderu, jako samostatný diskriminační důvod zákon uvádí i pohlavní/genderovou („nemi“) identitu. Český antidiskriminační zákon používá pojem pohlaví a specifikuje, že tento diskriminační důvod zahrnuje krom jiného i sexuální identifikaci. Termín sexuální identifikace je neobvyklý a nepoužívaný, v Komentáŕi k antidiskriminačnímu zákonu (Kvasnicová \& Šamánek, 2015) je interpretován jako genderová identita.

Rakouský školský zákon pochází z roku 1962, kdy sice deklaroval, že veřejné školy jsou přístupné bez rozdílu pohlaví, ovšem $v$ době jeho uvedení v platnost byly $v$ Rakousku ještě běžnou praxí genderově segregované školy. Zákon byl v průběhu let několikrát modifikován ve prospěch genderové rovnosti, $\checkmark$ roce 1975 byla zavedena koedukace a později byly zrušeny předměty rozlišující specificky dívčí a chlapecké ruční práce. $Z$ hlediska genderově citlivého vzdělávání jsou důležitější zákony upravující vzdělávání učitelů a učitelek. Vysokoškolský zákon explicitně uvádí, že vysoké školy vzdělávající budoucí učitele a učitelky musí uplatňovat strategii gender mainstreamingu ${ }^{11}$ a brát $v$ potaz nejnovější poznatky z genderových studií a genderově citlivých didaktik. Budoucí vyučující by rovněž měli být rozvíjeni

10 Jednotlivé dokumenty jsou uvedeny za seznamem literatury v části „Analyzované dokumenty“. $\checkmark$ textu popisujícím výsledky analýzy $z$ důvodu lepší čitelnosti $k$ jednotlivým dokumentům neodkazujeme, referenci uvádíme pouze $v$ prípadě, kdy využíváme prímé citace.

11 Gender mainstreaming je jedním z nástrojů prosazování genderové rovnosti. Spočívá v zahrnutí genderové perspektivy do všech fází (plánování, přípravy, realizace, hodnocení) rozhodovacích procesů a tvorby politik, projektů apod. V př́padě vyučujících by se jednalo o zahrnutí genderové perspektivy do přípravy, realizace a hodnocení výuky. 
ve svých genderových kompetencích a v oblasti rovného zacházení a rovnosti žen a mužů. Stejně tak zákon upravující práva a povinnosti vyučujících na základních a středních školách požaduje, aby vyučující měli genderové kompetence. Rakousko dále disponuje vzdělávacím principem, jenž se přímo věnuje prosazování rovnosti mezi muži a ženami, jenž byl v roce $1995^{12}$ začleněn do kurikula pro všechny typy škol rakouského vzdělávacího systému. Tento princip je povinný pro všechny učitele a učitelky a zavádí genderovou rovnost jako průřezové téma. Cílem tohoto principu je podpořit vyučující v přijímání jednotlivých kroků pro dosažení rovnosti mezi muži a ženami. Dle principu by otázky genderové rovnosti měly být zahrnuty ve vzdělávacím obsahu, učebnicích a dalších výukových materiálech. Princip si klade za cíl zvyšovat povědomí o pohlavně specifické socializaci, pohlavně specifické dělbě práce ve veřejném i soukromém sektoru, sexuálním násilí a reprodukci genderových stereotypů prostřednictvím výukových materiálů i aktérů vzdělávání. Dále chce u vyučujících podpořit reflexi vlastního jednání ve třídě a eliminovat všechny pohlavně specifické předsudky.

Mad'arský školský zákon $v$ obecných principech zmiňuje rovné zacházení, jež je vztaženo ke znevýhodněným studujícím ve smyslu zdravotního „postižení“ a sociálního znevýhodnění. Nezmiňuje se však o rovných přiležitostech ani o genderové rovnosti. Gender není zmíněn ani ve vysokoškolském zákoně, v němž je odkaz $\mathrm{k}$ rovným přiležitostem opět vztažen ke studujícím se znevýhodněním a těm na rodičovské dovolené. Můžeme říci, že mad’arské zákony upravující vzdělávání jsou vůči genderu a genderové nerovnosti slepé. $V$ uplynulých devíti letech od nástupu konzervativní vlády Viktora Orbána je však zřetelná postupně zesilující antigenderová tendence. Tato tendence je patrná i z ministerské vyhlášky z roku 2017, jež zrušila jedno z maturitních témat předmětu sociální studia věnující se genderové teorii a jež upravila znění rámcového kurikula pro biologii a rodinnou výchovu tak, aby eliminovala explicitní zmínky o genderu a rozlišení biologického pohlaví a genderové identity.

$\checkmark$ českém školském zákoně nalezneme obecný princip rovného př́stup ke vzdělání včetně rovného př́stupu na základě pohlaví. Zákon dále vymezuje obecné cíle vzdělávání, mezi nimiž je i „pochopení a uplatňování principu rovnosti žen a mužů ve společnosti” („Zákon č. 561/2004 Sb.“, 2019). Zákon uvádí, že proces vzdělávání by měl být zdokonalován v souladu s výsledky dosaženými ve vědě, na rozdíl od zmíněného rakouského vysokoškolského zákona však není explicitně uvedeno, že by měly být zohledněny i poznatky z oboru genderových studií. Ačkoliv školský zákon deklaruje obecný princip rovného zacházení na základě pohlaví a cíl odkazující $\mathrm{k}$ rovnosti žen a mužů, $v$ zákoně o vysokých školách a v nařízení vlády upravujícím pedagogické obory nenalezneme zmínku o genderu, genderové rovnosti nebo genderových kompetencích budoucích pedagogů a pedagožek. České legislativní dokumenty upravující vzdělávání budoucích učitelů a učitelek tak vykazují stejnou slepotu vůči genderové rovnosti jako ty mad'arské a nevytvářejí podmínky pro začlenění tématu genderové rovnosti do prípravy budoucích pedagogických pracovníků a pracovnic.

\subsection{Strategické dokumenty}

Všechny země disponují strategiemi pro prosazování genderové rovnosti. Mad'arsko má strategii z roku 2010, kterou přijala bývalá sociálně-liberální vláda. Strategie navazuje na dokumenty Evropské unie a poskytuje detailní evaluaci mad’arského vzdělávacího systému z hlediska genderu. Jako jeden z problémů zmiňuje i značné znevýhodnění romských žen, které z důvodu brzkého mateřství vypadávají ze základního vzdělávání. Strategie vyzývá k nestereotypnímu vzdělávání dívek a chlapců a navrhuje revizi kurikula, nastavení kritérií genderové vyváženosti pro učebnice a výukové materiály a tematizuje také násilí na ženách. Nicméně strategie nebyla po nástupu vlády Viktora Orbána implementována a žádné z navrhovaných opatření nebylo realizováno.

Rakousko implementuje evropskou strategii vzdělávání ET 2020, jež se věnuje mimo jiné i genderovým nerovnostem ve vzdělávání, podporuje genderovou vyváženost a tematizuje genderové stereotypy a zodpovědnost vyučujících při vytváření prostředí bez šikany a obtěžování včetně toho genderově

12 Ve školním roce 2018/2019 byla představena nová verze tohoto vzdělávacího principu, ta však již nebyla předmětem analýzy. 
podmíněného. $V$ minulých letech (od roku 2000) implementovalo ministerstvo školství tři akční plány, které se věnovaly prosazování genderové rovnosti, genderovému mainstreamingu a genderově citlivému vzdělávání ve školním vzdělávání i vzdělávání dospělých. Genderová rovnost je tak v Rakousku prostřednictvím strategických dokumentů prosazována o více než dekádu déle, než je tomu v Mad'arsku a České republice.

Česká republika má strategii vzdělávání, jež se jako ta rakouská odkazuje k evropské strategii ET 2020. Genderová rovnost v ní však není tematizována. Najdeme v ní pouze zmínku o tom, že mají být zajištěny rovné vzdělávací přiležitosti i výsledky pro všechny bez ohledu na pohlaví ( $v$ anglické verzi dokumentu uvedeném jako gender) a další charakteristiky. Zmíněna je také genderová nevyváženost učitelské profese. Více se strategie genderové nerovnosti ve vzdělávání nevěnuje. Ta je detailně rozebírána ve dvou strategických dokumentech věnujících se primárně genderové rovnosti. Jedním je strategický dokument uveřejněný MŠMT roku 2013, který předkládá přehledný obraz o problematice genderové nerovnosti včeském vzdělávacím systému a navrhuje opatření pro zlepšení. Používá genderově vyvážený jazyk, záměrně pracuje s termínem genderová ne/rovnost, ne pouze s termínem rovnost mužů a žen a diskutuje dopady genderových stereotypů na LGBTI+ osoby. Dalším strategickým dokumentem je vládní strategie pro rovnost žen a mužů, která sice popisuje problémy, kterým čelí český vzdělávací systém z hlediska genderu, a navrhuje konkrétní opatření, záměrně ale používá pouze slovní spojení rovnost žen a mužů a problémy, s nimiž se ve vzdělávání setkávají LGBTI+ osoby, nezmiňuje. Obě zmíněné strategie se odkazují na dokumenty Evropské unie a mezinárodní závazky České republiky. Vládní strategie uvádí, že je zdrojem pro každoročně aktualizované priority vlády pro prosazování rovnosti žen a mužů. Priority z roku 2018 požadují, aby genderová problematika byla zařazena do rámcových vzdělávacích programů, aby byla genderová rovnost zahrnuta do procesu posuzování učebnic, aby byla zajištěna podpora vzdělávání ICT v souladu s rovností žen a mužů a aby byla genderová rovnost zohledňována ve vzdělávání na základních a středních školách. České strategické dokumenty věnující se explicitně prosazování genderové rovnosti / rovnosti žen a mužů jsou zpracované odborníky a odbornicemi na genderovou problematiku a stanovují konkrétní cíle a opatření, jež by měly být přijaty, jejich naplňování je ovšem diskutabilní. Detailně propracovaná analýza a navrhovaná opatření ve specificky genderově orientovaných dokumentech se nedostávají do dokumentů obecnější povahy.

\subsection{Kurikulární dokumenty}

Jednotlivé země mají odlišný systém kurikulárních dokumentů, které se liší i v miřre detailnosti popisu vzdělávacího obsahu. Lze ale říci, že všechny země disponují dokumenty obecnější povahy definujícími obecnější cíle, hodnoty a principy vzdělávání a dokumenty nebo pasážemi dokumentů vztahujícími se ke konkrétním předmětům nebo vzdělávacím oblastem.

Rakouské obecné kurikulum explicitně zmiňuje gender mainstreaming a povinnost škol zabývat se otázkou genderu na všech úrovních výuky. Studující by měli být mimo jiné vedeni ke kritickému posouzení rolí, jež jsou přisuzovány jednotlivým pohlavím. Dokument dále specifikuje reflexivní koedukaci a genderově citlivou pedagogiku, když požaduje, aby vyučující rozvíjeli potenciál všech žáků a žákyň $v$ co nejširším slova smyslu bez genderově specifického stereotypizování a upravovali vzdělávací obsah a výukové metody, tak aby oslovily oba gendery. Vyučující by si rovněž měli být vědomi toho, jak jejich očekávání může ovlivnit výkony žáků a žákyň, a měli by mít alespoň základní vzdělání v oblasti genderových studií. Odkazy na gender nalezneme i v učivu některých konkrétních předmětů. Tělocvik by měl reflektovat genderově specifické potřeby. $V$ historii, sociálních studiích a politickém vzdělávání by se studující měli učit o genderové historii, o formách znevýhodnění žen v minulosti, o ženském hnutí i různých genderových konceptech. Kariérové poradenství by mělo nabízet možnost $k$ revizi tradičních postojů a co nejvíce rozšiřit možnosti volby povolání, zejména u dívek. Žáci a žákyně by se měli učit o různých rolích včetně dvojí zátěže, které čelí především ženy, a o možných řešeních. Děti by měly být podporovány ve schopnosti čelit genderovým předsudkủm, reflektovat genderovou segregaci na trhu práce i externí vlivy, které působí na utváření aspirací. 
Stejně tak v pracovních činnostech - technických a textilních pracích - je několikrát zdůrazněno, že by studující měli být podporováni vtom, aby si vyzkoušeli všechny činnosti bez ohledu na stereotypní očekávání. Gender je př́tomen rovněž v základech digitálního vzdělávání, kde nalezneme požadavek, aby se dostávalo rovných přiležitostí k participanci chlapcům i dívkám.

Rakouské kurikulum ve své obecné i předmětové rovině pracuje s poznatky o genderových stereotypech, které považuje za problematické, a podporuje vyučující v tom, aby reflektovali svá očekávání a snažili se rozvíjet potenciál všech žáků a žákyň. Nepřekračuje však rovinu binárního rozdělení na dívky a chlapce ani se blíže nevěnuje sexuální orientaci. $V$ biologii sice nalezneme požadavek, aby děti byly vedené $k$ přijetí vlastního těla a vlastní sexuality, explicitně ale existence LGBTI+ studujících není zmíněna.

Jak jsme naznačili již v části věnující se legislativním dokumentům, mad’arské kurikulum je značně ovlivněno současnou konzervativní politikou. Kromě důrazu na národní identitu a patriotismus je v obecném i rámcovém kurikulu pro jednotlivé předměty, jež je v porovnání s českým rámcovým vzdělávacím programem v popisu učiva detailnější, zřetelný důraz na rodinu zejména v její „tradični“" heteronormativní podobně. Např́klad pouze v kurikulu pro historii a sociální a občanská studia je rodina zmíněna dvaadvacetkrát (na rozdíl od žen, které se prakticky nevyskytují). Obecné kurikulum sice zmiňuje genderovou rovnost a antidiskriminaci jako jedny ze základních konceptů vzdělávání, ovšem dále se $k$ nim nevyjadřuje a většina dalších formulací souvisejících $s$ genderem odkazuje k biologicky daným odlišnostem mezi muži a ženami a z nich vyplývajících „přirozeně“ odlišných rolí mužů a žen ve společnosti. $V$ mad'arském jazyce se děti mají učit o rozdílech $v$ mužské a ženské komunikaci, $v$ prírodovědě o rozdílech mezi muži a ženami a souvislostí těchto rozdílů s pohlavními/genderovými rolemi (použit je výraz, jenž může být interpretován jako pohlaví i jako gender). Biologie a zdraví kromě poukazování na biologické rozdíly mezi muži a ženami a jejich role $\checkmark$ rodině a společnosti klade důraz na plodnost, početí, vývoj plodu a morální otázku potratu.

Více se zastavíme u průřezového tématu rodinná výchova, jehož obsah a vzdělávací cíle by měly být zahrnuty i do ostatních předmětů. Rodina je opět tematizovaná jako základní jednotka společnosti, kladen je důraz na rozdíly mezi muži a ženami a $v$ části věnované zodpovědné sexualitě nalezneme formulace jako - plodnost je poklad, o který je třeba se starat, plodná láska - dítě jako dar, zázrak inseminace, hodnota panenství/panictví. Dưraz je kladen na sexuální zdrženlivost, značný prostor je věnován vývoji plodu, těhotenství, péči o dítě a hodnotě lidského života od početí až po smrt. Zřetelná je konzervativní a tradicionalistická rétorika uvažující o sexualitě pouze v souvislosti s reprodukcí (v manželství), zejména pak ženská sexualita je redukována na reprodukční funkci. Existence LGBTI+ osob je neviditelná a je implicitně potlačovaná důrazem na heterosexuální partnerství. Jako ilustraci přistupu, jenž je zřetelný v celém kurikulu, uvedeme citaci z části rodinné výchovy věnující se sexualitě, mužské a ženské identitě a vztahům:

Cílem je pomáhat žákům od raného věku s posilováním jejich pohlaví / genderové identity v souladu s jejich genetickým pohlavím, s učením se o fundamentálních rozdílech mezi pohlavími (pohlavní charakteristiky, fungování mozku, komunikace atd.). ... Cílem je podpořit úspěšné hledání a výběr partnera. Je důležité, aby se žáci učili o formách mužsko-ženských vztahů a možnostech štěstí/deziluze, které v nich mohou zažít a aby rozvíjeli prorodinnou perspektivu. Měli by být dostatečně připraveni pro zralou, zodpovědnou, vyváženou a zdravou sexualitu vycházející z harmonického a štastného vztahu (manželství). Dále by měli být seznámeni s poznatky nezbytnými pro zdravý sexuální život. Výsledkem učení o kráse lidského početí a vývoji plodu by mělo být jejich porozumění tomu, že lidský život je pokladem od početí až po prirozenou smrt (srov. Rédai \& Sáfrány, 2019, s. 61-62).

Český rámcový vzdělávací program s pojmem gender neoperuje. $V$ charakteristice vzdělávací oblasti Člověk a společnost nalezneme informaci, že studující by měli být vzděláváni k rovnosti žen a mužů a v cílovém zaměření této vzdělávací oblasti nalezneme bližší specifikaci ve formě „utváření pozitivních vztahů $\mathrm{k}$ opačnému pohlaví v prostředí školy i mimo školu, k rozpoznávání stereotypního nahlí̌ení na postavení muže a ženy $v$ rodině, $v$ zaměstnání i v politickém životě, $k$ vnímání předsudků v nazírání na roli žen ve společnosti“ („MŠMT“, 2019, s. 52). V učivu výchovy k občanství najdeme však už pouze 
zmínku o přirozených a sociálních rozdílech mezi lidmi a o rovném postavení mužů a žen ( $v$ anglické verzi překvapivě přeložené jako genderová rovnost, jež má širší význam), ovšem bez bližší specifikace, co by mělo být obsahem. $V$ popisu vzdělávací oblasti Člověk a svět práce je uvedeno, že vzdělávací obsah je určen všem, dívkám i chlapcům bez rozdílu. Tato specifikace pravděpodobně odkazuje na dřivější praxi rozdělování pracovních činností podle genderu studujících. Ve vzdělávací oblasti výchova ke zdraví jsou do učiva zahrnuty poruchy pohlavní identity a sexualita jako součást formování osobnosti, ale opět bez bližší specifikace. Nespecifikována zůstává i zmínka o sexuální identitě v doplňujícím vzdělávacím oboru etická výchova.

Český rámcový vzdělávací program je $v$ otázce genderové rovnosti vporovnání srakouským i mad'arským kurikulem velmi vágní. Neobsahuje explicitní požadavek kritické reflexe genderových stereotypů a genderových rolí, nelegitimizuje ve svém znění diverzitu genderových identit (uvádí ji pouze jako poruchu) a sexuálních orientacíi ${ }^{13}$. Rámcový vzdělávací program je psán v generickém maskulinu, dívky jsou tak zmíněny pouze $v$ prípadě, kdy je potřeba zdůraznit odlišnost dívek a chlapců. Dívky a chlapci jsou stavěni do opozice - byt' je požadován jejich vzájemný respekt.

Ani $v$ jedné zemi není v kurikulárních dokumentech dáván gender explicitně do souvislosti s jinými osami nerovnosti.

\subsection{Př́ručky}

Mad’arsko nevydalo doposud žádnou př́ručku, jež by se věnovala genderu ve vzdělávání. Česká republika disponuje především příručkami vydanými neziskovými organizacemi, některé však vyšly i ve spolupráci s ministerstvem školství nebo na jeho zakázku. Nejaktuálnější je príručka z roku 2010 věnující se genderově vyváženému jazyku s cílem snižit diskriminaci žen v jazykové praxi a redukovat sexistické vyjadřování. Genderově vyváženému vyjadřování ve vztahu k transgender osobám se nevěnuje. Kvalitně zpracovaná je príručka z roku 2009 věnující se homofobii v žákovských kolektivech. Tato pracuje explicitně s pojmem gender a dalšími pojmy souvisejícími s homofobní šikanou a vysvětluje dopady genderových stereotypů na LGBTI+ osoby. Ze stejného roku pochází i príručka věnující se sexuální výchově, která sice obsahuje kapitolu věnující se prímo genderovým stereotypům v sexuální výchově, ale většina ostatních kapitol genderovou perspektivu nezahrnuje a obsahuje místy nejasnou terminologii odrážející esencialistický a medicínský př́stup k sexuálním menšinám. Posledním dokumentem je jednostránková pomůcka pro posuzování genderové korektnosti učebnic, jež formou otázek nabízí návod k reflexi genderové stereotypnosti výukových materiálů.

Součástí analýzy bylo sedm rakouských příruček vydaných ministerstvem školství nebo s jeho spoluprací či podporou od roku 1999 do roku 2016. Na rozdíl od České republiky jsou příručky novějšího data nebo jsou opětovně aktualizovány. Většina analyzovaných dokumentů se odkazuje k legislativě a strategiím Rakouska i Evropské unie, pracuje s genderem jako sociálním konstruktem a usiluje o maximální diverzitu a potírání stereotypů. Dvě příručky se věnují učebním materiálům - zobrazování žen a mužů - a způsobům, jak identifikovat $v$ učebnicích diskriminaci s ohledem na gender a sexuální orientaci. Tyto materiály jsou určeny jak tvůrcům a vydavatelům, tak vyučujícím a vedení škol. Jedna z príruček se věnuje genderově inkluzivnímu jazyku. Čtyři příručky jsou obecnějšího rázu a poskytují školám - vedení, vyučujícím, príípadně výchovným poradcům - návod a podporu k rozvíjení genderových kompetencí, zavádění gender mainstreamingu a celkově utváření inkluzivního prostředí. Příručky vysvětlují různé koncepty související s genderovou ne/rovností, jedna z nich překonává a dekonstruuje binární koncept genderu a dává gender do souvislosti s ostatními osami nerovností.

13 V části pro první stupeň, jež nebyla podrobena celkové analýze, nalezneme požadavek, aby se děti orientovaly v bezpečných způsobech sexuálního chování mezi chlapci a děvčaty v daném věku. Tato formulace nabízí prostor pro tematizaci sexuálního a genderově podmíněného násilí a obtěžování, byt' je otázkou, zda si ji tak vyučující vyloží, současně však připouští pouze heterosexuální sexuální chování. 


\subsection{Souhrnná zjištění}

V Rakousku se genderové rovnosti a genderově citlivému vzdělávání dostává institucionální i legislativní podpory. Požadavek na genderové kompetence vyučujících a uplatňování genderově citlivého vzdělávání je zakotven vlegislativě upravující vzdělávání pedagogů a pedagožek. Díky vzdělávacímu principu zavádějícímu genderovou rovnost jako průřezové téma prostupuje genderová perspektiva kurikulem. Rakouští vyučující mají oporu v př́ručkách, které pokrývají různé oblasti spojené s genderovou rovností ve vzdělávání. Genderové odlišnosti jsou konceptualizovány jako z velké části sociálně konstruované a genderové stereotypy jako problematické a pro žáky a žákyně omezující. Pojmy jako gender, genderová rovnost, genderové stereotypy, genderové kompetence apod. jsou užívány explicitně, některé starší dokumenty pracují s německým pojmem "Geschlecht", který odkazuje jak k biologickému pohlaví, tak genderu.

V mad'arských legislativních dokumentech genderová rovnost bud' chybí, nebo je definována vágně bez explicitního užití slova gender. Vyučující nemají oporu v žádné státem vydané příručce, jež by se genderově citlivému vzdělávání věnovala. Současné kurikulární dokumenty namísto rozmanitosti akcentují „tradični“ heteronormativní rodinu a biologickou rozdílnost mužů a žen a homogenizují přislušníky a př́slušnice ženského a mužského pohlaví. Potírána je diverzita genderových identit, sexuálních orientací i diverzita mezi ženami a mezi muži.

Česká republika disponuje kvalitně zpracovanými strategiemi i některými př́ručkami, institucionální a legislativní podpora však chybí. Odkazy k genderu jsou v dokumentech obecné (tedy na gender ne př́mo zaměřené) povahy nespecifické, legislativní a kurikulární dokumenty s pojmem gender explicitně neoperují, dokonce i jeden z klíčových strategických dokumentů uživá pouze pojmu rovnost mužů a žen namísto genderová rovnost. Kurikulární dokumenty sice obsahují zmínky o rovnosti žen a mužů, ale použité formulace vyjadřují predstavu dívek a chlapců jako opačných a odlišných a vybízejí k homogenizaci těchto dvou skupin. LGBTI+ studujícím je napříč analyzovanými dokumenty věnována minimální pozornost.

\section{Diskuse a závěr}

Cílem naší studie bylo porovnat, jak je gender a genderová rovnost koncipovaná ve vzdělávacích dokumentech v České republice, Mad'arsku a Rakousku. Všechny země se potýkají s genderovou nerovností ve formě genderové segregace ve vzdělávacích oborech, stereotypů ve výukových materiálech, stereotypních očekávání vyučujících, homofobní šikany či sexuálního obtěžování, každá však $k$ řešení těchto problémů přistupuje jinak. Rakousko genderovou nerovnost ve vzdělávání explicitně problematizuje a zhruba od poloviny 90 . let 20. století aktivně usiluje o zlepšení situace. Naopak současná mad'arská politická reprezentace prosazuje silný antigenderový, antifeministický a antiLGBTI+ diskurz, který se kromě omezování akademické svobody například rušením oborů genderových studií na univerzitách projevuje i úpravou kurikulárních dokumentů. Česká republika se nachází někde uprostřed mezi zmíněnými zeměmi. Genderová rovnost je prosazována, ale není považována za prioritní. Strategické cíle a navrhovaná opatření nejsou dostatečně naplňovány a genderově citlivé vzdělávání je rozvíjeno spíše neziskovým sektorem, který však čelí útokům některých politických představitelů a snahám o omezení jeho financování.

I Rakousko se stejně jako Česká republika a Mad'arsko potýká s určitou mírou averze vůči genderové rovnosti a nárůstem konzervativních tendencí, avšak díky dlouholetému prosazování genderového mainstreamingu a díky většímu počtu dokumentů, které se věnují vysvětlování genderových konceptů a problematizování genderových stereotypů, je pravděpodobně snaha o genderově citlivé vzdělávání více chápána a prijijimána jak ze strany vyučujících a vedení škol, tak ze strany rodičů. Delší rakouská tradice v prosazování genderové rovnosti je dána odlišnou historií zkoumaných zemí. V Rakousku v 60. a 70. letech proběhla tak zvaná druhá vina feministické emancipace, která v západních zemích spočívala mimo jiné $v$ úsilí o rovné zastoupení žen na trhu práce a rovný přístup ke vzdělání a která 
otevírala veřejnou diskusi o postavení žen a genderové rovnosti. Naopak nesvobodný charakter společnosti v Mad'arsku a České republice a omezení svobody shromažd'ovací umlčelo činnost ženských spolků, jež fungovaly před obdobím státního socialismu, a zamezilo možnosti sdílení zkušeností a formulování problémů a politických požadavků samotnými ženami (Havelková, 2009). Po demokratické transformaci nebylo téma rovnosti mužů a žen považováno v České republice ani Mad'arsku za klíčové a feminismus se setkával spiše s nepochopením. K prosazování genderové rovnosti tak začalo více docházet až s blízícím se vstupem do Evropské unie.

Na druhou stranu je však třeba poukázat na to, že je to právě Rakousko, které ze zkoumaných zemí vykazuje nejvyšší rozdíly ve výkonech dívek a chlapců i největší míru nerovnosti v platech. Rakousko je i přes výše zmíněný vývoj spíše konzervativní země, v níž delší dobu působil kapitalistický model muž - živitel, žena - $v$ domácnosti a $v$ níz ženy získaly právo být zaměstnané bez nutnosti souhlasu manžela až v 70. letech 20. století. Naopak Českou republiku a Mad'arsko spojuje společná historie období státního socialismu, který zaručoval formální (byt' ne faktickou) rovnost mužů a žen od 50 . let 20. století a zajistil přistup žen ke vzdělání a na pracovní trh dříve, než tomu bylo v Rakousku. Nicméně $\mathrm{i}$ díky déletrvající veřejné debatě se školám a vyučujícím, kteří usilují o inkluzivní školní prostředí, dostává v Rakousku ze zkoumaných zemí největší podpory v uplatňování genderově citlivého přístupu. Naopak současná mad'arská politická situace vytváří tlak jak na inkluzivně smýšlející vyučující, tak na žáky a žákyně, kteří se s tradičně vymezenými genderovými rolemi neidentifikují. Mad'arské školství tak rozhodně nesměřuje $\mathrm{k}$ inkluzi a rovným příležitostem pro všechny studující, ale vytváří prostředí, kde není prostor pro rozmanitost.

Co se týče České republiky, ke zlepšení situace by pomohlo ustanovení stálého oddělení pro genderovou rovnost na ministerstvu školství, tak jako je tomu v Rakousku, a začlenění požadavku genderové kompetence pedagogických pracovníků a pracovnic do príslušné legislativy. Tento požadavek by musel jít ruku v ruce s dalším vzděláváním pedagogických pracovníků a pracovnic. Ti již v dnešní době mohou absolvovat kurzy genderově citlivého vzdělávání, jejich nabídka je však omezená a jsou navštěvovány spíše vyučujícími, kteří k tématu genderu již jistou míru citlivosti mají. K zajištění inkluzivnějšího prostředí v českých školách by jistě pomohlo i detailnější a komplexnější začlenění genderové perspektivy do rámcových vzdělávacích programů. Tento krok byl stanoven jako jedna z priorit vlády pro prosazování rovnosti žen a mužů z roku 2018 a byl rozpracován i strategickým dokumentem MŠMT, jenž byl předmětem naší analýzy. Strategie MŠMT navrhuje, aby se genderová rovnost stala průřezovým tématem a aby rámcově vzdělávací program konceptualizoval gender jako sociálně utvářenou charakteristiku. Oba tyto požadavky jsou v Rakousku již aplikovány, v České republice jejich implementace stagnuje, a to i přesto, že byly i spolu sostatními výše zmíněnými opatřeními v minulosti již několikrát formulovány odbornicemi a odborníky na genderovou rovnost ve vzdělávání. Zmiňuje je např́ílad i Stínová zpráva o stavu rovnosti žen a mužů (Smetáčková, 2019), která mimo jiné doporučuje i zahrnutí genderové rovnosti mezi kritéria inkluzivního vzdělávání. Inkluzivní vzdělávání je však v české vzdělávací politice pojímáno úzce a genderovou perspektivu nezahrnuje. Podle našeho názoru je ale genderově citlivé vzdělávání důležitou součástí inkluze, chápeme-li ji jako vzdělávání, jež nabízí podporu a přijetí všem žákům a žákyním, podporuje rozmanitost a umožňuje studujícím rozvíjet se bez ohledu na společenské stereotypy a očekávání.

Studie byla podpořena programem Evropské unie Erasmus + prostřednictvím přidělení grantu projektu Towards Gender Sensitive Education (2017-1-CZ01-KA201-035485) a Masarykovou univerzitou v rámci projektu Akademické psaní ve vědeckém výzkumu (MUNI/A/1308/2018).

\section{Literatura}

Babanová, A., \& Miškolci, J. (2007). Genderově citlivá výchova: Kde začít? Př́ručka pro vyučujicí základních a středních škol vydaná v rámci projektu Rovné př́ležitosti v pedagogické praxi. Praha: Žába na prameni, o. s. 
Babanová, A. (2019). Dvanáct ověřených metod pro rozvoj kolegiální spolupráce. Praha: Gender Studies, o.p.s.

Batalha, L., \& Reynolds, J. K. (2013). Gender and personality: Beyond gender stereotypes to social identity and the dynamics of social change. In M. K. Ryan, \& N. R. Branscombe (Eds.), The SAGE handbook of gender and psychology (pp. 165-182). London: SAGE Publications, Inc.

Bussey, K. (2013). Gender development. In M. K. Ryan, \& N. R. Branscombe (Eds.), The SAGE handbook of gender and psychology (pp. 81-99). London: SAGE Publications, Inc.

Český statistický úřad. (2019, Červen 15). Zaostřeno na ženy a muže 2018. Dostupné z https://www.czso.cz/csu/czso/zaostreno-na-zeny-a-muze-2018

Dombos, T., Krizsan, A., Verloo, M., \& Zentai, V. (2012). Critical frame analysis: A comparative methodology for the 'Quality in Gender+ Equality Plicies' (QUING) project. Budapest: Central European University.

Drexlerová, A. (2018). Kluků je škoda, holky na to nemají: Genderové aspekty v hodnocení nejslabších žáků trídy. Studia paedagogica, 23(1), 9-28. Dostupné z https://www.phil.muni.cz/journals/index.php/studia-paedagogica/article/view/1720/1940

Forum for African Women Educationalist (FAWE). (2019, Červenec 20). Gender responsive pedagogy: A teacher's handbook. Dostupné z http://www.ungei.org/files/FAWE_GRP_ENGLISH_VERSION.pdf

Gullberg, A., Andersson, K., Danielsson, A., Scantlebury, K., \& Hussénius, A. (2018). Pre-service teachers' views of the child - Reproducing or challenging gender stereotypes in science in preschool. Research in Science Education, 48(4), 691-715. https://doi.org/10.1007/s11165-0169593-z

Haring, S., \& Mörth, A. (2009). „School and teaching from a gender perspective - Gender sensitive didactics" Review and evaluation of a continuing education workshop for Austrian grammer school teachers. In D. Gronold, B. Hipfl, \& L. Lund Pedersen (Eds.), Teaching with the third wave new feminists' explorations of teaching and institutional contexts (pp. 127-148). Utrecht: Athena.

Havelková, B. (2009). Genderová rovnost v období socialismu. In M. Bobek, P. Molek, \& V. Šimíček, Komunistické právo v Československu. Kapitoly z dějin bezpráví (s. 179-206). Brno: Masarykova univerzita.

Charbonnier, É., Hatteschweiler, C., \& Graziani, P. (2015). Risque suicidaire et stress chez les jeunes homosexuels. Psychologie Française, 60(3), 209-222. https://doi.org/10.1016/j.psfr.2015.01.001

Jarkovská, L. (2013). Gender před tabulí: Etnografický výzkum genderové reprodukce v každodennosti školní třídy. Praha-Brno: Sociologické nakladatelství v koedici s Masarykovou univerzitou.

Jarkovská, L., Lišková, K., \& Šmídová, I. a kol. (2010). S genderem na trh: Rozhodování o dalším vzdělávání patnáctiletých. Praha-Brno: Sociologické nakladatelství v koedici s Masarykovou univerzitou.

Johns, M. M., Poteat, V. P., Horn, S. S., \& Kosciw, J. (2019). Strengthening our schools to promote resilience and health among LGBTQ Youth: Emerging Evidence and research priorities from the state of LGBTQ Youth Health and Wellbeing Symposium. LGBT Health, 6(4), 146-155. https://doi.org/10.1089/lgbt.2018.0109

King, M., Semlyen, J., Tai, S. S., Killaspy, H., Osborn, D., Popelyuk, D., \& Nazareth, I. (2008). A systematic review of mental disorder, suicide, and deliberate self harm in lesbian, gay and bisexual people. BMC Psychiatry, 8(1). https://doi.org/10.1186/1471-244x-8-70 
Krišová / Genderově citlivé vzdělávání jako prostředek k vytváření inkluzivního školního ...

Kolářová, J. (Ed.). (2014). Volba povolání bez předsudků. Metodika projektového dne pro základní školy. Praha: Gender studies, o.p.s.

Kolářová, K. (2012). Disability studies: Jiný pohled na „postiženi““. In K. Kolářová (Ed.), Jinakost, postižení kritika. Společenské konstrukty nezpůsobilosti a hendikepu (s. 11-40). Praha: Sociologické nakladatelství.

Kollmayer, M., Schober, B., \& Spiel, Ch. (2018). Gender stereotypes in education: Development, consequences, and intervention. European Journal of Developmental Psychology, 15(4), 361-377. https://doi.org/10.1080/17405629.2016.1193483

Kvasnicová, J., \& Šamánek, J. (2015). Antidiskriminační zákon. Komentár̆. Praha: Wolters Kluwer.

Lahelma, E. (2014). Troubling dicourses on gender and education. Educational Research, 56(2), 171-183. https://doi.org/10.1080/00131881.2014.898913

Mizala, A., Martínez, F., \& Martínez, S. (2015). Pre-service elementary school teachers' expectations about student performance: How their beliefs are affected by their mathematics anxiety and student's gender. Teaching and Teacher Education, 50, 70-78. http://dx.doi.org/10.1016/j.tate.2015.04.006

MŠMT. (2019, Květen 30). Rámcový vzdělávací program pro základní školy. Dostupné z http://www.msmt.cz/file/43792/

Rédai, D., \& Sáfrány, R. (Eds.). (2019). Gender in national Education documents and teaching resources, and in teachers' pedagogical approaches adn everyday teaching practices in Austria, the Czech Republic and Hungary. Comparative report for the Erasmus+ project "Towards Gender Sensitive Education", project No. 2017-1-CZ01-KA201-035485. Dostupné z http://gendersensed.eu./outputs/

Slavík, L. (2019, Červenec 20). Gender a genderově senzitivní pedagogika optikou českých škol a vyučujicích. Genderové informační centrum NORA, o.p.s. Dostupné z https://gendernora.cz/_files/200000443-a4bdea5b71/Zpr\%C3\%A1va-TGSE_final_.pdf

Smetáčková, I. (2019, Červenec 20). Gender ve škole. Příručka pro budoucí i současné učitelky a učitele. Otevřená společnost, o.p.s. Dostupné z http://www.otevrenaspolecnost.cz/knihovna/otevrenka/prosazovani-genderoverovnosti/gender-ve-skole-ucitele.pdf

Smetáčková, I. (Ed.). (2019, Červenec 20). Stínová zpráva o stavu genderové rovnosti v České republice $v$ roce 2015. Praha: Česká ženská lobby. Dostupné z https://czlobby.cz/sites/default/files/dokumenty/stinova_zprava_2015.pdf

Smetáčková, I. (2016). Genderové představy a vztahy. Sociální a kognitivní aspekty vývoje maskulinity a feminity v průběhu základní školy. Praha: Sociologické nakladatelství.

Smetáčková, I., \& Braun, R. (2009). Homofobie v žákovských kolektivech. Homofobní obtěžování a šikana na základních a středních školách - jak se projevuje a jak se proti ní bránit. Dostupné z https://www.vlada.cz/assets/udalosti/homofobie_web.pdf

Smetáčková, I., \& Pavlík, P. (2011). Sexuální obtěžování na vysokých školách: Teoretické vymezení, metodologický př́stup, výzkumné výsledky. Sociologický časopis, 47(2), 361-386. Dostupné z https://www.jstor.org/stable/pdf/23073210.pdf?refreqid=excelsior\%3A574f135fc30de9523 3280ec37893b885

Smetáčková, I., \& Pavlík, P. (2012). Genderově motivované a sexuální obtěžování na středních školách: Hranice vhodného chování. Sociální studia 9(3), 11-30. Dostupné z https://journals.muni.cz/socialni_studia/article/view/5960/5072 
Krišová / Genderově citlivé vzdělávání jako prostředek k vytváření inkluzivního školního ...

Vad'urová, L. (2011). Genderově stereotypní vzorce chování v pedagogické komunikaci na druhém stupni základní školy. Studia paedagogica, 16(1), 211-224. Dostupné z https://www.phil.muni.cz/journals/index.php/studia-paedagogica/article/view/130/232

Veřejný ochránce práv. (2019, červenec 29). Být LGBT+ v Česku. Zkušenosti LGBT+ lidí s předsudky, diskriminací, obtěžováním a násilím z nenávisti. Dostupné z https://www.ochrance.cz/fileadmin/user_upload/DISKRIMINACE/Vyzkum/VyzkumLGBT.pdf

Vohlídalová, M. (2009). Sexuální obtěžování na vysoké škole. V ČR neexistující problém?. Gender, rovné príležitosti, výzkum, 10(2), 20-29. Dostupné z https://www.genderonline.cz/uploads/b9b2849ecf3a1c5fea8c893521899f7eca485452_sex ualni-obtezovani-na-vs.pdf

Zákon č. 561/2004 Sb., o předškolním, základním, středním, vyšším odborném a jiném vzdělávání (školský zákon). (2019, Červenec 27). Zákony pro lidi. Dostupné z https://www.zakonyprolidi.cz/cs/2004-561 


\section{Př́loha}

\section{Analyzované dokumenty}

\section{Legislativní dokumenty}

24/2017. (X. 3.) EMMI rendelet egyes köznevelési tárgyú miniszteri rendeletek módosításáról [Ministerial Decree 24/2017 (03/10) on the modification of certain ministerial decrees in public education]. (2019, Červenec 28). Wolters Kluwer. Retrieved from https://net.jogtar.hu/jogszabaly?docid=A1700024.EMM\&timeshift=20180101\&txtreferer=00 000001.txt

2011. évi CXC. törvény a nemzeti köznevelésröl [Act CXC/2011 on National Public Education]. (2019, Červenec 28). Bács-Kiskun Chamber of Commerce and Industry. Retrieved from http://bkmkik.hu/attachments/article/62/Hatályos\%20köznevelési\%20törvény.doc

2003. évi CXXV. törvény az egyenlő bánásmódról és az esélyegyenlőség előmozdításáról [Act CXXV/2003 on Equal Treatment and the Promotion of Equal Opportunities]. (2019, Červenec 28). Egyenlő Bánásmód Hatóság. Retrieved from http://www.egyenlobanasmod.hu/data/eselytorveny.pdf

BMBWK (Bundesministerium für Bildung, Wissenschaft und Kultur [Federal Ministry of Education, Science and Culture]). (n.d.) Unterrichtsprinzip "Erziehung zur Gleichstellung von Frauen und Männern [Educational principle "Education to Equality between Women and Men"]. (2019, Červenec 28). Bundesministerium Bildung, Wissenschaft und Forschung. Wien: BMBWK. Retrieved from https://bildung.bmbwf.gv.at/schulen/unterricht/prinz/PDFzuPubID311_9716.pdf?61ec1o

Bundes-Gleichbehandlungsgesetz (Bundesgesetz über die Gleichbehandlung im Bereich des Bundes BGIBG) [Federal Act on Equal Treatment in Federal Service BGBI]. No. 100/1993 in der geltenden Fassung. (2019, Červenec 28). Rechtsinformationssystem des Bundes (RIS). Retrieved from http://www.ris.bka.gv.at/GeltendeFassung.wxe?Abfrage=Bundesnormen\&Gesetzesnummer $=10008858$

Dienstrechts-Novelle 2013 - Pädagogischer Dienst [Service Law Amendment] BGBI. I Nr. 211/2013. (2019, Červenec 28). Rechtsinformationssystem des Bundes (RIS). Retrieved from https://www.ris.bka.gv.at/Dokumente/BgblAuth/BGBLA_2013_I_211/BGBLA_2013_I_211.ht $\mathrm{ml}$

Gleichbehandlungsgesetz GIBG (Bundesgesetz über die Gleichbehandlung) [Federal Act on Equal Treatment] BGBI. I No. 66/2004 in der geltenden Fassung. (2019, Červenec 28). Rechtsinformationssystem des Bundes (RIS). Retrieved from https://www.ris.bka.gv.at/GeltendeFassung.wxe?Abfrage=Bundesnormen\&Gesetzesnummer $=20003395$

Hochschulgesetz 2005, HG (Bundesgesetz über die Organisation der Pädagogischen Hochschulen und ihre Studien) [Federal Law on the Organisation of University Colleges of Teacher Education (Higher Education Act 2005)] BGBI. I Nr. 30/2006, Amendment 2010 BGBI. I Nr. 47/2010. (2019, Červenec 28). Rechtsinformationssystem des Bundes (RIS). Retrieved from https://www.ris.bka.gv.at/GeltendeFassung.wxe?Abfrage=Bundesnormen\&Gesetzesnummer $=20004626$

Nařízení vlády č. 275/2016 Sb., o oblastech vzdělávání ve vysokém školství. (2019, Červenec 27). Zákony pro lidi. Dostupné z https://www.zakonyprolidi.cz/cs/2016-275

Schulorganisationsgesetz, SchOG (Bundesgesetz vom 25. Juli 1962 über die Schulorganisation) [School Organization Act] BGBI. Nr. 242/1962 in der geltenden Fassung. (2019, Červenec 28). Rechtsinformationssystem des Bundes (RIS). Retrieved from 
http://www.ris.bka.gv.at/GeltendeFassung/Bundesnormen/10009265/SchOG\%2c\%20Fassun g\%20vom\%2005.06.2018.pdf

Zákon č. 198/2009 Sb., o rovném zacházení a o právních prostředcích ochrany před diskriminací a o změně některých zákonů (antidiskriminační zákon). (2019, Červenec 27). Zákony pro lidi. Dostupné z https://www.zakonyprolidi.cz/cs/2009-198

Zákon č. 111/1998 Sb., o vysokých školách a o změně a doplnění dalších zákonů (zákon o vysokých školách). (2019, Červenec 27). Zákony pro lidi. Dostupné z https://www.zakonyprolidi.cz/cs/1998-111

Zákon č. 561/2004 Sb., o předškolním, základním, středním, vyšším odborném a jiném vzdělávání (školský zákon). (2019, Červenec 27). Zákony pro lidi. Dostupné z https://www.zakonyprolidi.cz/cs/2004-561

\section{Strategické dokumenty}

BMBWK (Bundesministerium für Bildung, Wissenschaft und Kultur [Federal Ministry of Education, Science and Culture]). (2002). Aktionsplan 2003 - Gender-Mainstreaming und geschlechtssensible Bildung (Aktionszeitraum 2003-2006) [Action Plan 2003 - Gender Mainstreaming and gender sensitive education (2003-2006)]. Wien: BMBWK.

BMUK (Bundesministerium für Unterricht und kulturelle Angelegenheiten [Federal Ministry of Education and Cultural Affairs]). (2000). Aktionsplan 2003 - Gender-Mainstreaming \& Frauenförderung in Schule und Erwachsenenbildung (Aktionszeitraum 2000-2003) [Action Plan 2003 - Gender Mainstreaming and promotion of women in schools and adult education (20002003)]. Wien: BMUK.

BMUK (Bundesministerium für Unterricht und kulturelle Angelegenheiten [Federal Ministry of Education and Cultural Affairs]). (1997). Aktionsplan 2000 - 99 Maßnahmen zur Förderung der Gleichstellung im Bereich von Schule und Erwachsenenbildung (Aktionszeitraum 1997-2000) [Action Plan 2000 - 99 measures to promote gender equality for schools and adult education (1997-2000)]. Wien: BMUK.

European Commission and European Council. (2019, Červenec 31). Joint Report of the Council and the Commission on the implementation of the strategic framework for European cooperation in education and training (ET 2020). New priorities for European cooperation in education and training (2015/C 417/04). Retrieved from http://eur-lex.europa.eu/legalcontent/EN/TXT/PDF/?uri=CELEX:52015XG1215(02)\&from=EN

European Commission. (2019, Červenec 31). Strategic framework for European cooperation in education and training ET 2020. Retrived from http://ec.europa.eu/education/policy/strategic-framework_en

Government of Hungary. (2019, Červenec 31). A Nők és Férfiak Társadalmi Egyenlöségét Elösegítő Nemzeti Stratégia - Irányok és Célok 2010-2021. [National Strategy for the Promotion of Social Equality of Women and Men - Directions and Goals 2010-2021.] Retrieved from http://docplayer.hu/1703788-A-nok-es-ferfiak-tarsadalmi-egyenloseget-elosegito-nemzetistrategia-iranyok-es-celok-2010-2021.html

MŠMT. (2019, Červenec 28). Stav genderové rovnosti a návrh střednědobého strategického plánu v oblasti genderové rovnosti v resortu ministerstva školství, mládeže a tělovýchovy. Dostupné z http://www.msmt.cz/file/31791

MŠMT. (2019, Červenec 28). Strategy for Education Policy of the Czech Republic until 2020. Dostupné z http://www.vzdelavani2020.cz/images_obsah/dokumenty/strategy_web_en.pdf 
Úřad vlády ČR. (2019, Červenec 28). Vládní strategie pro rovnost žen a mužũ v České republice na léta 2014-2020. Dostupné z https://www.vlada.cz/assets/ppov/rovne-prilezitosti-zen-amuzu/Projekt_Optimalizace/Strategie-pro-rovnost-zen-a-muzu-v-CR-na-leta-2014-2020.pdf

Vláda ČR. (2019, Červenec 28). Aktualizovaná opatření Priorit a postupů vlády při prosazování rovnosti žen a mužů na rok 2018. Dostupné z https://www.vlada.cz/assets/ppov/rovne-prilezitosti-zena-muzu/dokumenty/Aktualizovana_opatreni.pdf

\section{Kurikulární dokumenty}

BMBWF (Bundesministerium für Bildung, Wissenschaft und Forschung [Federal Ministry of Education, Science and Research]). (2019, Květen 30). Lehrpläne der AHS-Unterstufe [Curricula for Academic Secondary School - Lower Cycle]. Retrieved from https://bildung.bmbwf.gv.at/schulen/unterricht/lp/Ip_ahs_unterstufe.html

BMBWF (Bundesministerium für Bildung, Wissenschaft und Forschung [Federal Ministry of Education, Science and Research]). (2019, Květen 30). Lehrplan der Neuen Mittelschule [Curriculum for New Secondary School]. . Retrieved from https://bildung.bmbwf.gv.at/schulen/unterricht/lp/Ip_nms.html

Kerettanterv az általános iskola 5-8. évfolyamára [Frame curriculum for years 5-8 of primary school]. (2019, Květen 29). Oktatáskutató és Fejlesztő Intézet. Retrieved from http://kerettanterv.ofi.hu/

Lehrpläne allgemeinbildende höhere Schulen, BGBI. Nr. 88/1985 in der geltenden Fassung [Curricula for Academic Secondary School, Federal Law Gazette No. 88/1985 in its current version]. (2019, Květen 29). Rechtsinformationssystem des Bundes (RIS). Retrieved from http://www.ris.bka.gv.at/GeltendeFassung/Bundesnormen/10008568/Lehrpl\%c3\%a4ne\%20 \%e2\%80\%93\%20allgemeinbildende\%20h\%c3\%b6here\%20Schulen\%2c\%20Fassung\%20vom\% 2013.06.2018.pdf

Lehrpläne Neue Mittelschulen, BGBI. II Nr. 185/2012 zuletzt geändert durch BGBI. II Nr. 71/2018 [Curricula for New Secondary School, Federal Law Gazette II No. 185/2012, last amended by Federal Law Gazette II No. 71/2018]. (2019, Květen 29). Rechtsinformationssystem des Bundes (RIS). https://www.ris.bka.gv.at/Dokumente/Bundesnormen/NOR40201120/NOR40201120.pdf

MŠMT. (2019, Květen 30). Rámcový vzdělávací program pro základní školy. Dostupné z http://www.msmt.cz/file/43792/

Nemzeti Alaptanterv 2012 [National Core Curriculum 2012]. (2019, Květen 30). Oktatáskutató és Fejlesztő Intézet. Retrieved from http://ofi.hu/sites/default/files/attachments/mk_nat_20121.pdf

\section{Příručky}

BMB (Bundesministerium für Bildung [Federal Ministry of Education]). (2019, Červenec 20). Gender Kompetenz \& Gender Mainstreaming. Kriterienkatalog für Schulen [Gender Competence \& Gender Mainstreaming: Criteria catalog for schools]. Wien: BMB. Retrieved from http://pubshop.bmbf.gv.at/download.aspx?id=249

BMB (Bundesministerium für Bildung [Federal Ministry of Education]). (2019, Červenec 20). Geschlechtergerechtes Formulieren [How to formulate gender inclusively]. Wien: BMB. Retrieved from https://bildung.bmbwf.gv.at/schulen/unterricht/ba/gs/If_geschlechter_form_2016.pdf?6aan r6 
BMUKK (Bundesministerium für Unterricht, Kunst und Kultur [Federal Ministry of Education, Arts and Culture]). (2019, Červenec 20). Leitfaden zur Darstellung von Frauen und Männern in Unterrichtsmitteln [Guideline for representation of women and men in teaching materials]. Wien: BMUKK. Retrieved from https://bildung.bmbwf.gv.at/schulen/unterricht/ba/leitfadengeschlechter_10336.pdf?61ech z

Hladschik, P. (2019, Červenec 20). Empfehlungen für nicht-diskriminierende Schulbücher, Fokus Gender und sexuelle Orientierung [Guidelines on how to identify Discrimination in Textbooks, focusing on Gender and sexual Orientation]. Wien: Edition polis. Retrieved from www.politiklernen.at/dI/MpulJMJKomlolJqx4KJK/edpol_2016_Nicht_diskriminierende_Schulbuecher_we b.pdf

Hofbauer, Ch., \& Westfall-Greiter, T. (2019, Červenec 20). School Walkthrough. Ein Werkzeug für kriteriengeleitete Schulentwicklung [School Walkthrough - a Tool for Criteria based School Development]. Wien: ZLS (Bundeszentrum für lernende Schulen). Retrieved from www.nmsvernetzung.at/pluginfile.php/16635/mod_glossary/attachment $/ 4287 /$ SchoolWalkt hrough.pdf

MŠMT. (2009). (2019, Červenec 20). Sexuální výchova - vybraná témata. Praha: MŠMT ve spolupráci s VúP. Dostupné z $\quad$ https://www.eduin.cz/wpcontent/uloziste/311/Metodicke_materialy/Sexualni_vychova_vybrana_temata.pdf

MŠMT. (2019, Červenec 30). Pomůcka při posuzování genderové korektnosti učebnic. Dostupné z http://www.msmt.cz/vzdelavani/zakladni-vzdelavani/pomucka-pri-posuzovani-genderovekorektnosti-ucebnic

Radler M., Unger, P., \& Widmann, A. (2019, Červenec 20). Gendersensible und genderkompetente Schulentwicklungsberatung [Gender sensitive and gender competent School Development Consulting]. Wien: Bundesministerium für Bildung. Retrieved from https://bildung.bmbwf.gv.at/schulen/unterricht/ba/gekos_schulentwicklungsberatung.pdf?6 1edq2

Smetáčková, I., \& Braun, R. (2019, Červenec 20). Homofobie v žákovských kolektivech. Praha: Sekretariát Rady vlády ČR pro lidská práva, Úřad vlády. Dostupné z https://www.vlada.cz/cz/urad-vlady/vydavatelstvi/vydane-publikace/homofobie-vzakovskych-kolektivech--homofobni-obtezovani-a-sikana-na-zakladnich-a-strednich-skolach--jak-se-projevuje-a-jak-se-proti-ni-branit-79188/

Tschenett, R., \& Bors, A. (2019, Červenec 20). Geschlechtergerechtigkeit und - gleichstellung als Aufgabe im Rahmen von SQA [Gender equality and equal opportunities as task of SQA]. Wien: Bundesministerium für Bildung. from http://www.nmsvernetzung.at/pluginfile.php/13019/mod_forum/attachment/8516/5MF_Au sgabe13.pdf

Valdrová J., Knotková-Čapková, B., \& Paclíková, P. (Eds.). (2019, Červenec 30). Kultura genderově vyváženého vyjadřování. Praha: MŠMT. Dostupné z http://www.ceskaskola.cz/2010/01/msmtkultura-genderove-vyvazeneho.html 